\title{
A RELAÇÃO ENTRE PARCELAMENTO ILEGAL DO SOLO URBANO E A AUSÊNCIA DE MAPAS CADASTRAIS NOS REGISTROS IMOBILIÁRIOS BRASILEIROS
}

\author{
Ellade Imparato' \\ Mestre em Direito Internacional da Faculdade \\ de Direito da Universidade de São Paulo.
}

Resumo:

Uma análise conclusiva sobre o parcelamento ilegal do solo urbano e a deficiência, há meio século, dos registros imobiliários no país.

Abstract:

A conclusive analysis on the illegal partition of the urban ground and the deficiency, has century half, of the real estate registers in the country.

Unitermos: Lei dos Registros Públicos; loteamento; títulos de propriedade

1. Introdução

\subsection{O Problema}

Quando aprofundamos nossos estudos sobre o usucapião constitucional urbano como instrumento para obter a segurança na posse das terras particulares ilegalmente parceladas e vendidas em lotes de terreno à população de baixa-renda, percebemos que não-basta a nova concepção dada à função social da propriedade pela Constituição de 1988. Para efetivá-la são necessárias muito mais que interpretações doutrinárias ou mesmo jurisprudenciais. Para tornar a função social da propriedade eficaz fazem-se necessárias mudancas estruturais no ordenamento juridico brasileiro.

I. Artigo entreguc, $\mathrm{cm}$ um primciro estudo, para o J" Congresso Brasilciro de Dircito Urbanístico c Gestão Urbana, Bclo Horizontc, MG, dezembro de 2000 
Um dos aspectos a ser revisto é o próprio cadastramento imobiliário. Como fica claro a partir do estudo de caso que fizemos, ao final exposto, a ausência de vínculo entre o título de propriedade e sua representação na cartografia urbana permite todo o tipo de parcelamento ilegal do solo. Desta forma, o comprador de um lote de terreno nunca poderá saber se o título de propriedade apresentado pelo vendedor referese ou-não àquela gleba parcelada. Se a ausência de vinculo entre o título registrado e sua representação gráfica no espaço urbano favorece todo o tipo de parcelamento ilegal, favorece especialmente a grilagem ${ }^{2}$ de terras.

Além de dificultar a compra de lotes de terreno e facilitar a grilagem de terras, a ausência de obrigação legal de manutenção e atualização de mapas cadastrais em nossos Cartórios de Registro de Imóveis dificulta as decisões do Poder Judiciário, quando confrontado por um conflito onde mais de um proprietário reclama para si os direitos sobre a mesma gleba. Pois, em tese, diante de dois ou mais títulos registrados para uma dada área nem o Judiciário pode resolver o conflito, uma vez que para o Código Civil, basta o registro ou a transcrição do documento de transferência para a aquisição da propriedade (art. 530, I).

A ausência de mapaş cadastrais facilita os conflitos de terras na medida em que permite uma aparente, ou real, superposição de títulos de propriedade. Por outro lado, a dissociação entre o registro imobiliário e o cadastro fiscal mantido pelas Prefeituras Municipais dificulta o poder de polícia da Municipalidade para fazer cumprir a função social da propriedade urbana. Esta dificuldade fica clara, por exemplo, nos obstáculos encontrados pelo Município de São Paulo em controlar a ocupação das áreas de mananciais, pois o nome do contribuinte não guarda relação necessária com o proprietário.

\subsection{A Abordagem}

Para este primeiro estudo, abordamos o problema primeiramente analisando de forma dogmática o contexto legal em que se insere a ausência de mapas cadastrais em nossos Cartórios de Registro de Imóveis. No que tange à aquisição do dominio, fazemos um corte epistemológico para examinar apenas o contrato de venda e compra como forma de sua transferência.

2. $\Lambda$ origem da denominação "grilagem de terras" não ć unânime. Uns alcgam que o nome foi dado face ao barulho feito pelos "grilciros", para fazcrem valer suas intençõcs; ć scmelhante a uma revoada de grilos. Outros dizcm qué a scmelhança se dá na cor dos vellos documentos ressuscitados pelos grilciros $\mathrm{cm}$ suas artimanhas para obterem scus titulẹs de propricdade. 
Desta forma, abordamos alguns aspectos desses contratos perante o Código Civil brasileiro. Dentro deste limite analisamos as normas havidas pela Lei Federal n. 6.015/73, conhecida como a "Lei dos Registros Públicos"

Expomos a modificação legislativa sobre a questão registrária de terras ao longo da história brasileira. Sobre a lei vigente, fazemos uma explanação de seus objetivos e elencamos as regras impostas para que um título seja registrado e apontamos as Leis Federais que regulam o parcelamento do solo urbano. Estas questões teóricas são apresentadas da forma mais sintética possível. A explanação teórica é feita apenas e tão-somente para mostrar ao leitor os limites legais da questão.

Então, abandonamos a dogmática para examinamos um conflito de terras, onde foi constatada a sobreposição de dois títulos de propriedade, ambos registrados, portanto igualmente válidos. O conflito estudado, ainda não definitivamente resolvido, refere-se ao parcelamento "Parque Novo Lar" situado em São Mateus, ná zona leste da Cidade de São Paulo, (plantas 1, 2 e 3). Este caso é particularmente interessante não-só porque o Judiciário foi obrigado a decidir entre dois títulos de propriedade que, aparentemente, se sobrepõe mas, também, por ser uma região da Cidade, onde os conflitos de terra remontam ao século XVI.

Desta forma, historiamos as questões das terras da zona leste desta Capital, antes de apresentarmos o caso propriamente dito. O estudo do caso foi elaborado a partir de entrevistas que nos foram generosamente concedidas pelos líderes da comunidade e moradores do "bairro".3 José Aguiar e Pedro Pastor Avalo.

A partir dessas entrevistas, examinamos os documentos referentes ao caso, coletados e cedidos pelo advogado Antônio Benedito Margarido, que representa os moradores, há cerca de vinte anos, em sua luta pela regularização de suas terras. Os documentos examinados trazem cópias das peças dos processos judiciais e administrativos que se desenvolveram a partir do final dos anos 60 e o início dos 80 , período em que o conflito se desenrolou.

Não menos relevante para este artigo foi a sua representação cartográfica feita a partir da base de dados do Instituto Polis, colocada à nossa disposição pela Dra. Raquel Rolnik. A execução acurada do traballıo cartográfico foi cuidadosamente levado

3. No Municipio de Sĩo Paulo, os asscntamentos informais sào chamados de "bairros" por scus moradores e pelas pessoas que ncles atuam. 
a cabo pelo arquiteto Fernando Bastos. ${ }^{4}$ Nossas idéias empíricas encontram respaldo na bibliografia apresentada no final que situa as questões aqui levantadas.

\section{Alguns Aspectos Sobre a Evolução das Normas Jurídicas Brasileiras}

\subsection{O início da questão registrária}

A compreensão dessas disputas territoriais não é tarefa simples, uma vez que os conflitos têm origem em questões históricas que podem ser traçadas até o século XVI. Por outro lado, par e passo com os problemas fundiários houve uma evolução legislativa. Aqui fazemos outro corte epistemológico e deixamos de examinar a legislação fundiária vigente durante o Brasil colonial, que conheceu algumas mudanças durante os quatrocentos anos em que foi aplicada.

Mesmo porque, o caso que discutimos, em que pesem seus estreitos vínculos com questões jurídicas coloniais, desenvolveu-se a partir dos finais dos anos 60 deste século. Desta forma, iniciamos este estudo após a Proclamação da Independência.

Só então e a partir da Constituição, de 1824, admitiu-se a existência de propriedade privada no País. Através da Lei n. 601, de 1850, conhecida com Lei de Terras, ficaram estabelecidos os procedimentos de regularização que deveriam ser seguidos para transformar as concessões administrativas outorgadas pela Coroa portuguesa. Aquela Lei permitiu, também, a legalização das posses das terras que fossem ocupadas sem nenhum título.

Ambas, regularização e legalização, seriam possíveis se o possuidor apresentasse uma planta com o levantamento planialtimétrico da gleba e houvesse princípio de cultura agrícola no local. As terras não-legitimadas ou regularizadas seriam consideradas devolutas e sua ocupação foi criminalizada. A ocupação de terra devoluta era punível com prisão e multa.

Paralelamente aos procedimentos de regularização e à figura da terra devoluta, a Lei de Terras criou um tipo de registro fundiário, que ficou conhecido como Registro Paroquial. Nos termos do Decreto, de 1854, que a regulamentou, aquele registro consistia da entrega ao padre responsável pela paróquia da situação do imóvel da declaração de

4. O arquitcto não conseguiu localizar nos mapas as árcas constantes das transcriçõcs. A partir das descrições dos perímetros, verificamos que os marcos constantes não constam de nenhum dos três Icvantamentos da Cidade utilizados para o trabalho (Sara Brasil, da década de 1930, Gegram, de $1974 \mathrm{c}$ Emplasa, de 1981 - todos com cscala 1:10.000). 
próprio punho, em duas vias, com a descrição da gleba de terras havida. As cópias eram seladas, com o pagamento do imposto obrigatório. Uma delas era devolvida ao declarante e outra era mantida nos arquivos da paróquia.

A ausência da declaração ou a falta de boa-manutenção de seu arquivamento na paróquia constituíam ilícito e eram puníveis com multas progressivas. Todavia, a declaração não fazia prova de propriedade e sim prova da posse declarada. Desta forma, o Registro Paroquial consistiu em um cadastro de terras, antes de um registro imobiliário. Mesmo assim, imediatamente após a publicação do Código Civil, foi admitido o registro daquelas declarações no Registro Geral de Imóveis.

As descrições das terras declaradas não se baseavam em qualquer tipo de levantamento topográfico. Tampouco, mantinham as paróquias mapas cartográficos de suas circunscrições territoriais. As descrições eram pitorescas. Baseavam-se em marcos instáveis, tais como córregos, árvores e cercas. Raramente informavam as medidas lineares das confrontações, área ou as direções precisas seguidas pelo terreno. Exatamente como as descrições havidas nas concessões portuguesas, era impossível pelas descrições feitas perante o Registro Paroquial localizar a área de terras declarada em um mapa cartográfico.

Em 1864, a Lei n. 1.237 criou outra espécie de registro imobiliário desvinculado da Igreja Católica. O Registro Geral de Imóveis, então criado, tinha por função fazer e manter o registro das transações imobiliárias dentro de sua circunscrição territorial. Desta forma foi dada a possibilidade de serem registradas tanto a venda e compra, quanto os ônus constituídos sobre os imóveis. Aqueles Registros Gerais não mantinham mapas cartográficos de seus territórios, nem era exigido que as transações registradas fossem baseadas em dados topográficos precisos. Declarada a República, em novembro de 1889, o Governo provisório que se instalou, desvinculou o Estado brasileiro da Igreja Católica e conseqüentemente extinguiu o Registro Paroquial.

Aquele Governo provisório estabeleceu pelo Decreto n.451 B, de 31.05.1890, que os Registros Gerais criados, em 1864, deveriam seguir o método registrário conhecido como Método de Torrens. Assim, as transações imobiliárias passaram a ser transcritas em fichas. Novamente, não houve sequer menção da necessidade de serem mantidos pelos Registros Gerais mapas cartográficos de suas circunscrições e de vinculá-los às transcrições. Este é um dado particularmente interessante, pois o método registrário do australiano Torrens é reconhecidamente eficaz, justamente por esta conexão necessária entre a cartografia da região e o título transcrito. 
Com a entrada em vigor do Código Civil, em 01.01.1917, para a tradição da propriedade imóvel, tornou-se obrigatório a transcrição registrária da transação (art. 530, I). Além da transcrição obrigatória, o Código Civil estabeleceu forma específica para o título a ser transcrito como essencial para a validade do ato jurídico (art. 82). Sendo assim, o registro obrigatório era possível se o ato jurídico tivesse a forma de Escritura Pública lavrada por notário ou fosse decorrente de decisão judicial. Aparentemente o legislador civilista quis dar maior segurança aos atos jurídicos sobre a propriedade imobiliária que se tornou o pilar do ordenamento jurídico brasileiro.

Apesar desses cuidados formais, o legislador civilista não traçou novos parâmetros essenciais para a modificação da antiga ordem. Desta maneira, as transcrições, desde então obrigatórias para a tradição da propriedade imóvel, continuaram a ser feitas nas fichas, conforme o prescrito no Método de Torrens. Porém, sem sua necessária vinculação ao mapa cartográfico da região. Este método híbrido, de criação autóctone, não deu bons resultados. Sua transformação, no entanto, demorou muitos anos. As características fundamentais do Registro Geral foram mantidas até 1973.

O método registrário foi alterado pela Lei Federal n. 6.015, em 31.12.73. Esta Lei conhecida como "Lei dos Registros Públicos" aboliu o Método de Torrens para os novos registros. Desta forma, paulatinamente as antigas transcrições vão se transformando em matrículas. A Lei dos Registros Públicos determina as regras formais que os Cartórios Registrários devem seguir para dar "autentiCidade, segurança e eficiência aos atos juridicos" (art. $1^{\circ}$ ). Esta Lei fixa as regras registrárias de todos os Cartórios de Registro, inclusive de imóveis, e determina que todos eles serão administrados por uma pessoa física de Direito Privado nomeada de acordo com as regras dadas pelo Poder Judiciário do Estado-membro (art. $2^{\circ}$ ).

\subsection{O parcelamento do solo}

O Código Civil não estabeleceu regras para o parcelamento do solo urbano ou rural. O Decreto-lei n. 58/37, estabeleceu-as. A partir de então, todo o parcelamento do solo urbano precisa ser aprovado pela Prefeitura Municipal e registrado no Cartório de Imóveis anteriormente à venda dos lotes de terreno.

Determinou que, além da planta e planos aprovados do loteamento, o loteador estava obrigado a fazer registrar o modelo de contrato de compromisso e venda e compra que celebraria com os promitentes compradores que quisessem comprar os imóveis a prazo. 
Aquele Decreto-lei não trouxe nenhuma norma urbanística, mesmo assim poucos parcelamentos cumpriram suas determinações. Todavia, conseguiu coibir as perdas impostas aos promitentes compradores de baixa renda, como ocorrera, até então, com os contratos celebrados com respaldo no art. 1.080 do Código Civil.

Desta forma, se durante os anos 20 e até 1937, durante a gradual intensificação do processo de urbanização paulistano, a perda das parcelas das prestações do pagamento eram corriqueiras, a partir daí estas perdas se restringiram a compra de lotes em loteamentos grilados. Todavia, surgiram as figuras dos loteamentos irregulares e clandestinos, ou seja, aqueles que apresentam alguma irregularidade na sua aprovação, registro ou implementação e aqueles que não foram registrados.

O Decreto-Lei n. 58/37 conheceu algumas alterações trinta anos mais tarde através do Decreto-Lei n. 271/67. A grande mudança, no entanto, deu-se somente em 20 de dezembro de 1979, com a publicação da Lei n. 6.766.

Nos anos 70, a crise do petróleo trouxe o fim do denominado "milagre econômico" e possibilitaram o início do lento processo que acarretou o fïm do regime autoritário, sob tutela militar (1964/88). O fim do modelo econômico imposto, a partir de 1964, enfraqueceu a "linha dura militar" e trouxe a volta dos movimentos populares. Estes, cujos participantes sentiam diretamente as conseqüiências da explosão dos loteamentos irregulares e clandestinos, a partir dos anos 50 , obtiveram profunda alteração do Decreto-Lei n. 58/37.

De fato, a Lei n. 6.766/79 apresentou muitas inovações. Determinou normas urbanísticas para a aprovação dos parcelamentos e criminalizou a conduta da venda de lotes de terreno sem prévia aprovação e registro. Além disso, criou a figura do loteamento popular e possibilitou a regularização fundiária pela Prefeitura Municipal dos parcelamentos feitos em desacordo com as normas jurídicas vigentes à época da sua implantação.

A possibilidade de aplicação de índices mais flexíveis para a aprovação e implantação de loteamentos populares e a de regularização de loteamentos irregulares e clandestinos desencadearam uma série de programas de regularização fundiária em vários Municípios brasileiros. Por outro lado, a criminalização da conduta do parcelador ilegal é apontada como o fator que levou à favelização das cidades brasileiras.

É dificil ligar a favelização somente à criminalização de uma dada conduta. Outros fatores certamente influíram na intensificação desse processo, especialmente a recessão econômica e o crescimento da inflação monetária verificados especialmente a partir dos anos 80 . Todavia, a verdade é que, desde então, pelo menos 
na Cidade de São Paulo, a oferta de lotes ilegais diminuiu consideravelmente, enquanto a população favelada aumentou 2,5 mil vezes entre 1973 e 1993.5

De qualquer forma, a Lei n. 6.766/79 foi parcialmente alterada pela Lei n. 9.785, publicada em 29.01.99. As alterações introduzidas são importantes. É interessante notar que, por exemplo, foram flexibilizados os índices urbanísticos dando poder aos Municípios para fixá-los. Desta forma, atendeu-se tanto aos preceitos da Constituição, de 1988, quanto às estratégias fixadas pela Agenda Habitat, ou seja, é o governo local que deve ter a autonomia para a gestão urbana. A nova Lei alterou, também, a Lei n. 6.015/73 para possibilitar o registro da cessão dos direitos possessórios quando da imissão provisória na posse, nas expropriações por interesse social promovidas por qualquer dos entes federados.

Não conhecemos qualquer estudo sobre o impacto da Lei n. 9.785/99 na ocupação do solo urbano brasileiro. Cumpre aqui observar que o acréscimo de uma alínea a um artigo da Lei n. 6.015/73 se de fato solicitou o problema da posse da terra dos ocupantes, enquanto não se chega a sentença final do processo desapropriatório, não alterou a essência daquela Lei. Desta forma, como as normas legais anteriores que dispuseram sobre o parcelamento do solo a estrutura das normas registrárias foi mantida.

\subsection{A natureza jurídica das normas e as formalidades do Registro de Imóveis}

As normas registrárias são basicamente procedimentais. A preocupação dessas normas é regulamentar como um título deve ser registrado, os livros que devem ser mantidos, protocolos e prenotações. Além disso essas normas se preocupam com outras formalidades, tais como: por quem e como o título deve ser lavrado para habilitálo ao registro, a quantidade de cópias que devem ser apresentadas, e, especialmente, quem e como será nomeado o responsável pelos Cartórios.

Tal é a preocupação do legislador com esta última questão que a Constituição Federal determina que os serviços notariais e registrários devem ser mantidos por pessoas físicas privadas, sob delegação do Estado (art. 236). Este artigo foi objeto da Lei Complementar n. 8.935, de 18.11.94. A Lei informou que os serviços notariais e registrários têm a função de garantir "publiCidade, autentiCidade, segurança e eficácia aos atos jurídicos" (art. $1^{\circ}$ ). Aparentemente, entendeu o legislador que esta garantia será dada pelo estrito cumprimento de ritos.

5. A população favclada que cra de ccrca de 74 mil, cm 1973, saltou para quasc 2 milhões de pessoas, cm 1993, scgundo dados da FIPE. 
De fato, a Lei de 1994 teve o escopo de determinar os mecanismos para operacionalizar a delegação de poderes aos agentes privados responsáveis pelo serviço, antes que o mérito e o conteúdo dos títulos passiveis de registro. A Lei n. 8.935 afirma que a delegação para operar aqueles serviços dão fé púbica aos atos praticados pelos agentes delegados (art. $3^{\circ}$ ), traz responsabilidade civil e criminal para os mesmos (arts. 22 a 24), e, finalmente, determina que o agente tem a obrigação de respeitar as normas técnicas dadas pelo Poder Judiciário Estadual (art. 30, XIV).

De fato, cada Cartório de Registro está vinculado ao Poder Judiciário dos Estados-membros. ${ }^{6}$ Isto significa que as regras prescritas pela Lei n. 6.015/73 são completamente desvinculadas dos cadastros fiscais mantidos pelo Município. De qualquer forma, tanto as normas trazidas pelo art. 30, XIV da Lei complementar, de 1994, quanto aquelas determinadas, em 1973, cingem-se às formalidades burocráticas que devem ser respeitadas para o registro de um título de transferência de domínio. Assim, passamos a examinar as regras burocráticas trazidas pela Lei dos Registros Públicos para o registro de títulos imobiliários.

\subsection{1 - As normas jurídicas prescritas na Lei de Registros Públicos}

As normas jurídicas prescritas na Lei de Registros Públicos são rígidas para o registro de qualquer ato jurídico. Determinam o que pode ser registrado, o Cartório competente para o registro e, sobretudo, como se deve proceder ao registro. Para o registro imobiliário, abandonadas as transcrições previstas pelo Método de Torrens, foi adotado o sistema alemão de matrículas.

O novo método não é ruim em si. Funciona muito bem em locais com ocupação do solo já consolidada e devidamente mapeada. Não é o caso do Brasil, onde justamente sempre foi evitada a vinculação entre o título e sua inserção na mapografia da Cidade. Desta forma, a intenção declarada da Lei - dar segurança aos atos jurídicos registrados - nem sempre ocorre para os imóveis.

A Lei n. 6.015 determina que o ato registrário deve ser transcrito em livro. Os livros devem ser mantidos no Cartório registrário responsável pela circunscrição onde está localizado o imóvel. O ato jurídico passível de registro deve conter a descrição do imóvel, sua situação com rua com o número dado pela Prefeitura Municipal, sua área ou metragens lineares de sua confrontações (dependendo de como já estiver descrito em registro anterior), e o nome dos confrontantes. Constará, também, o nome e qualificação do proprietário.

6. O Estado tem responsabilidade objctiva pelo registro. 
Se o proprietário for pessoa jurídica, a Escritura de venda e compra do imóvel só será registrada se forem apresentadas as Certidões Negativas de Débito do INSS e da Receita Federal. ${ }^{7}$ O número do cadastro na Prefeitura Municipal do Imposto Predial e Territorial Urbano IPTU ou, na União, do Imposto Territorial Rural - ITR tem inscrição obrigatória na matrícula (art. 176, I1). Para o registro do ato jurídico, no Estado de São Paulo, deve ser apresentado o comprovante de pagamento do Imposto de Transmissão de Bens lmóveis ITBI por ato inter-vivos ou causa-mortis.

Os atos jurídicos poderão ser objeto de registro ou de averbação. São averbados os atos que não se referem à transmissão do domínio, tais como modificação de nome de rua, número do imóvel na rua, alteração do estado civil do proprietário, etc. Se o que estiver averbado ou registrado prejudicar alguém, o prejudicado pode pedir sua retificação (art. 860, Código Civil). A diferença entre retificar um ato jurídico averbado ou registrado são relativas à forma e à autoridade a qual o pedido é dirigido.

As alterações relativas às averbações são requeridas através de petição dirigida ao Oficial Maior do Cartório, onde o título está registrado. À petição assinada pelo proprietário, pelo prejudicado ou por quemn legalmente os represente, com firma reconhecida, é juntada a cópia autenticada ou original do documento que prova a alteração.

As retificações do registro propriamente dito só serão admitidas por determinação judicial. Assim, se qualquer aspecto da descrição do imóvel estiver incorreto caberá àquele que tiver legitimidade para requer sua retificação pleiteá-la em Juízo. Somente após o devido processo legal, citados pessoalmente os confrontantes, e o transito em julgado da sentença poderá ser obtido o mandado de retificação. Este mandado será, então, apresentado ao Cartório registrário para o registro da retificação.

Podemos dizer, portanto, que são averbadas as características do imóvel ou fatos jurídicos que a lei considera menos importantes. Enquanto, são registrados todos os atos jurídicos que se referem ao domínio. De qualquer forma, para ser registrado ou averbado o instrumento do ato jurídico apresentado precisa ser original ou sua cópia autenticada e firmas reconhecidas em Cartório.

Os instrumentos registráveis que envolvam transação do dominio ou do domínio útil sobre imóvel são aqueles, nos termos da Lei n. 6.015/77 (art. 221, I a IV), celebrados perante notário público no Brasil ou perante agente público de Consulado brasileiro no Exterior. Os instrumentos particulares admitidos por lei poderão ser 
registrados desde que, além da descrição do imóvel idêntica a previamente registrada, tragam a qualificação de todos os contratantes, sejam celebrados perante pelo menos duas testemunhas, com todas as firmas reconhecidas por notários públicos.

Os atos jurídicos celebrados no Exterior, fora dos consulados, deverão primeiramente ser validados pelo Supremo Tribunal Federal. Finalmente, poderão ser registradas decisões judiciais. De qualquer forma, o instrumento jurídico para ser registrado deverá sempre trazer a descrição do imóvel exatamente igual a que já se encontra registrada.

Como já dissemos, tanto os Cartórios de Registro Imobiliário quanto os Cartórios de Notas são vinculados aos Poder Judiciário Estadual e não aos Municípios onde estão situados. Porém, enquanto cada Cartório de Registro de lmóveis tem uma circunscrição territorial específica, dentro de uma determinada Comarca, como limite de sua área de atuação, os atos jurídicos passíveis de registro poderão ser celebrados perante qualquer notário sediado em território brasileiro.

A criação de novos serviços de registro imobiliário estão ligados à expansão da Comarca onde estão situados, ou seja, apesar de sua desvinculação jurídica à estrutura Municipal, a criação de novos Cartórios de Registro de Imóveis está ligada à expansão territorial urbana.

Assim, a criação de uma nova Comarca, como também de novos serviços notariais ou registrários que são fruto de decisão do Poder Judicial do Estado-membro, derivadas tanto ao adensamento populacional quanto à expansão urbana e à criação de novos Distritos e Municípios.

Desta forma, o crescimento do número de Cartórios vinculados ao Poder Judicial Estadual decorre do processo de urbanização. A falta de controle sobre a expansão urbana verificada nos Municípios brasileiros, que assistiram impassíveis ao crescimento de suas periferias, com a ocupação da área rural e degradação do meio ambiente, é a mesma dos Cartórios vinculados ao Poder Judicial. Os Cadastros Municipais mantêm, ainda que muito precariamente, uma conexão com a ocupação do solo urbano, já os Cartórios são completamente alheios à realidade territorial sobre a qual atuam.

Esta questão é mais grave para os Serviços de Registro de Imóveis. Estes, como vimos, só podem atuar dentro de uma circunscrição territorial específica. Todavia, não mantêm mapa cadastral sobre suas respectivas circunscrições territoriais. Desta forma, quando muito terão a planta de um lote de terreno ou de uma gleba de terras. Nunca terão a representação gráfica e científica do todo constituído pela malha dos diferentes espaços ocupados dentro de suas circunscrições territoriais. 
Assim, podemos afirmar que as normas e regras prescritas pela Lei n. 6.015/73, para o registro de um instrumento jurídico imobiliário, não passam de uma longa lista de prescrições burocráticas. Ora, o domínio imobiliário que só será transferido pelo seu registro, diz respeito diretamente a um direito real exercido sobre um território determinado. A Lei, no entanto, não se preocupa com o espaço físico e sim com o estrito cumprimento de todas as formalidades necessárias ao seu registro, presumindose que uma vez registrado este espaço exista de verdade.

Desta forma, qualquer dos instrumentos enumerados pelo art. 167 , inciso I, alíneas 1 a 36, da Lei n. 6.015/73 poderão ser registrados, cumpridas as exaustivas formalidades legais, independentemente de sua realidade espacial. Conseqüentemente, possibilita-se a superposição de títulos de propriedade. É exatamente o que ocorreu no caso concreto que passamos a examinar.

\section{O Estudo de Caso}

\subsection{Os primeiros assentamentos}

Para o entendimento da questão fundiária da zona leste da Cidade de São Paulo há a necessidade de recuarmos no tempo até praticamente a data da sua fundação. Entre os séculos XVI e XIX, as várias concessões de terras feitas na região, sem a devida demarcação cartográfica, permitiram que durante o século XX se desenvolvessem inúmeros conflitos fundiários.

Estes conflitos envolveram disputas judiciais entre a União, o Estado, o Município de São Paulo e particulares. Os conflitos sobre aquelas terras afetaram diretamente os adquirentes de boa-fé que compraram lotes e casas na região durante o processo de expansão urbana da Cidade.

Assim, já em 1580, os jesuítas obtiveram uma sesmaria da Coroa portuguesa em seus arredores. Esta sesmaria, como de costume, abrangia uma gleba de terras imensa, com cerca $270 \mathrm{~km}$ _ Cobria toda a zona leste da Cidade até onde hoje se localiza o bairro da Móoca, e parte das municipalidades vizinhas hoje existentes, tais como Mogi das Cruzes, Guarulhos, Itaquaquecetuba e Santo André (Planta 2). Esta sesmaria foi concedida à Companhia de Jesus para a catequese e aculturação dos índios Guaianáses que habitavam a região.

8. Não foi possívcl mapcar o aldcamento. No cntanto, a partir da planta da árca mctropolitana $\dot{c}$ possivel percebcr suas dimensõcs. 
Os jesuítas pretendiam impedir a escravização daqueles índios e a expulsão de suas terras. De acordo com a legislação portuguesa, só os índios selvagens poderiam ser escravizados. Na verdade, a história do País mostra que eram justamente os índios cristianizados e aculturados os preferidos à servidão. Assim, os esforços da Companhia de Jesus foram em vão. Por volta de 1710, já não mais havia quaisquer índios no imenso aldeamento, que ficou conhecido como São Miguel-Guarulhos.

Os Guaianáses acabaram perdendo suas terra, porque no início do século XVII a Coroa permitiu que a Câmara de Vereadores passasse a conceder terras em sesmaria, para sua posterior ratificação. Durante aquele século e o início do seguinte, a Câmara de Vereadores de São Paulo concedeu inúmeras sesmarias sobre aquele aldeamento. Quando a Carta Régia chegou à São Paulo, em 1733, sem a ratificação das sesmarias concedidas e determinando que aquela, de 1580 , deveria prevalecer e os Guaianáses deveriam voltar às suas terras, já era tarde. Neste sentido, a Câmara respondeu à Metrópole, dizendo que não poderia cumprir a determinação real pois não mais havia índios na região.?

O processo terminou em 1745 , com a ratificação da Coroa das sesmarias dadas pela Câmara. Assim, em 1850, com a possibilidade dada pela Lei n. 601 para a regularização das sesmarias, as sesmarias dadas pela Câmara foram transformadas em propriedades pelos herdeiros e sucessores dos sesmeiros.

A mesma Lei, como vimos, criou a figura das terras devolutas e determinou que as terras não-regularizadas da forma que estabeleceu, voltariam ao patrimônio da nação. Estas terras devolvidas seriam leiloadas em hasta pública, e o dinheiro apurado seria utilizado para financiar a importação de mão-de-obra livre européia (arts. 18 e 19).

Ruy Cirne Lima relatou que, no final do Império, o Congresso Nacional percebeu que a Lei de Terras não havia atingido seu objetivo de desenvolvimento agrícola. Ainda, constatou que não se conhecia com precisão as terras devolutas que haviam sido vendidas. Assim, o Congresso Nacional propôs a alteração da Lei n. 601, na sessão de 1888. As modificações não foram aprovadas e, talvez, por isto mesmo, o regime republicano incorporou-as ao novo sistema jurídico brasileiro.

O primeiro Governo republicano permitiu, por Decreto, a criação de bancos agrícolas para fomentar esta atividade econômica e financiar colônias agrícolas e o assentamento da mão-de-obra livre dos colonos. Estas foram as bases da concessão

9. HOLSTON, James: Legalizando o Ilegal, São Paulo, Revista Brasileira de Ciências Sociais, n. 8, 1993, p. 81 
dada ao engenheiro Ricardo Medina, em 1890. Em 1891, o engenheiro transferiu esta concessão para seu banco privado, o Banco Evolucionista absorveu os 50 mil hectares ao longo das margens do Rio Tiete.

Também, em 1891, a primeira Constituição republicana transformou o regime do Estado brasileiro, que assumiu o caráter de federação, e elevou as Províncias a Estados-membros. Assim, as antigas Províncias ganharam mais autonomia e para elas foram transferidas as terras devolutas localizadas em seus territórios.

Apesar da transferência das terras devolutas, quando, em 1892, o Banco Evolucionista apresentou a medição de apenas metade da área que lhe fora concedida, em uma das margens do Rio Tietê, a União decidiu cancelar a concessão sobre as terras localizadas na outra margem. Desta forma, aquelas terras retornariam ao patrimônio da União.

O Estado de São Paulo, que havia cedido os direitos sobre aquela metade de concessão, contestou a determinação da União. O Supremo Tribunal Federal decidiu a questão somente em 1928 para dizer que a metade da concessão, sobre a qual havia sido feita a medição, deveria ser havida como condomínio indivisível entre o Banco Evolucionista e o Estado de São Paulo.

Ocorre que, no meio tempo, o Banco Evolucionista, faliu em 1900. Antes da falência dera em garantia sua concessão confirmada ao Banco Real de Crédito. O Banco Real de Crédito faliu em 1909; a concessão dada em garantia foi à hasta pública e terminou arrematada por um de seus sócios.

O acórdão do Supremo, que determinou a propriedade em condomínio indivisível da metade da concessão, outorgada em 1890, também confirmou suas finalidades. Assim, tanto os sucessores do Banco Evolucionista quanto o Estado de São Paulo receberem a concessão sobre aquelas terras com o dever de usá-la para a fundação de colônias agrícolas. Todavia, nem o Estado nem os sucessores dos direitos do Banco cumpriram aquela determinação legal.

Ambas as partes utilizaram o acórdão de forma diversa. Enquanto os sucessores do Banco a utilizavam para vender suas terras a terceiros e fazer toda espécie de negócios jurídicos, o Estado de São Paulo opunha-se contra toda e qualquer regularização fundiária, através de ações de usucapião para terras localizadas na zona leste da Capital.

Una vez que a descrição da área, cuja concessão foi confirmada pelo acórdão mencionado, era imprecisa, a transcrição que gerou também o foi. Desta forma, tanto os sucessores do Banco Evolucionista puderam comercializar muito mais do que 
de direito poderiam, quanto o Estado de São Paulo sentia-se no direito de reclamar seus supostos interesses em Juízo contra qualquer regularização na zona leste.

Mesmo deixando de lado as oposições apresentadas em Juízo pela Municipalidade, face a outras concessões outorgadas ao Município na zona leste durante o Império, pode-se dizer que aquela vasta região da Cidade viveu uma série de conflitos de terras durante um século diante de um lado da oposição do Estado, e de outro de sua incapaCidade de produzir um cadastro de imóveis confiável. De fato, a União só deixou de contestar as ações de usucapião naquela região no dia 7 de abril deste ano com a publicação da Súmula Administrativa n. 4, promulgada pelo Advogado Geral da União. O Estado de São Paulo havia abdicado de suas pretensões, em 1986.

A União que nunca havia deixado a disputa. Diante da decisão do Supremo Tribunal Federal sentia-se no direito de reclamar seus interesses pela metade da concessão que lhe fora devolvida. Teve sua posição fortalecida pela publicação do Decreto-lei n. 9.760, em setembro de 1946. O Decreto-lei deu uma arma poderosa à União para suas reclamações de direitos sobre a região.

Aquela norma jurídica elencou os bens de domínio da União, entre os quais os extintos aldeamentos indígenas (art. $1^{\circ}, \mathrm{h}$ ). Como o extinto aldeamento de São Miguel-Guarulhos abrangia toda a zona leste da Cidade, melhor se sentia a União para se opor às ações de usucapião, mesmo se a jurisprudência majoritária da Justiça Federal, desde a década de 80 , opinava pela inconstitucionalidade daquele Decreto-lei no que diz respeito aos extintos aldeamentos, uma vez que não foi recepcionado pela Constituição Federal, de 1946, publicada poucos meses depois.

Assim, o Município e o Estado de São Paulo desistiram de suas pretensões na década de 80 e a Procuradoria do Estado, em 1986, oficiou recomendando a publicação de Decreto presidencial para que a União fizesse o mesmo. No entanto, esta demorou 24 anos para reconhecer o óbvio, ou seja, não tinha qualquer respaldo jurídico para se opor às ações de usucapião sobre terras particulares naquela região.

O certo é que todos os litígios havidos entre os atores estatais e particulares sobre as terras da zona leste, até hoje, não conseguiram deslindar as questões dominiais sobre a região. Lá se sobrepõem títulos de domínio, havidos por concessões de uso mais antigas e mais recentes, dos quais derivaram nebulosos títulos de propriedade.

Desta forma, a história de títulos nebulosos, de legitimidade precária, dos assentamentos na zona leste da Cidade de São Paulo iniciou-se com a outorga de sesmarias pela Câmara Municipal, no século XVI, sobre área já concedida. Perpetuouse ao longo dos séculos diante da ausência de mapas cadastrais em nossos Cartórios de 
Registro de Imóveis. A ausência de mapas cadastrais gera obstáculos para a segurança da posse dos lotes comprados em parcelamentos, pois permite a sobreposição, real ou ficta, de títulos de propriedade e deixa o Poder Judiciário sem instrumentos adequados para resolver os conflitos de terra.

Portanto, mesmo com o novo entendimento da União Federal, os conflitos sobre as terras da zona leste da Cidade levarão gerações até serem dirimidos mantidà a atual legislação registrária ou até que esta venha a ser alterada para que se obrigue a manutenção de mapas cadastrais atualizados pelos nossos Cartórios. Os conflitos ocorridos no loteamento denominado "Novo Lar", em São Mateus, que examinamos a seguir, irão demonstrar a dimensão dessas questões jurídicas.

\subsection{O Loteamento "Novo Lar"}

No final dos anos 60, o loteamento, denominado "Novo Lar" (Planta $5),{ }^{10}$ foi anunciado pela mídia e divulgado, também, através da distribuição de belos panfletos por toda a zona leste da região metropolitana de São Paulo. O loteamento concebido e planejado pela empresa Lar Nacional oferecia à venda casas, com seus respectivos lotes, a preços muito convidativos.

$\mathrm{O}$ marketing de venda oferecia vários planos de pagamento, diferentes tipos de casas, e a opção dada ao comprador de recebê-las acabadas ou semiprontas. A empresa anunciava que linhas de crédito bancário do Sistema Financeiro de Habitação seriam obtidas para o pagamento das unidades e finalização das obras. Foram oferecidas ao mercado 10 mil unidades habitacionais no local.

Aquele empreendimento imobiliário, apesar de não ter sido aprovado pela Prefeitura Municipal e registrado nos termos do Decreto-lei n. 58/37, obteve enorme sucesso. A empresa Lar Nacional organizava visitas ao local, levando os interessados com peruas. Lá chegando, o interessado via os trabalhos de terraplanagem e o início da construção das casas, visitava uma fábrica de blocos, o lago de águas cristalinas e a execução do projeto de captação daquelas águas para as casas. Desta forma, o interessado, vendo um canteiro de obras em plena atividade, desconhecendo o descumprimento das determinações legais para a comercialização de lotes de terrenos e a edificação de casas, as de unidades foram vendidas.

Todavia, das 10 mil unidades colocadas à venda, somente 516 foram

10. Chegou-sc a csta representação combinando-sc um vôo de 1971 (GEGRAM) com o lcvantamento do Mctrô de 1974. 
entregues. Nenhuma delas foi acabada. Os compradores mais persistentes e com mais sorte conseguiram ao menos receber uma das 516 casas, mesmo que tenham tido que acabá-las com seus próprios recursos. Centenas de pessoas firmaram contrato, iniciaram seus pagamentos e nada receberam em troca.

Por outro lado, as importâncias a serem pagas não eram tão-acessíveis como uma conta menos cuidadosa poderia levar a crer. Segundo os depoimentos prestados, ficava contratado que o comprador deveria fazer uma poupança por um prazo de tempo que variava de um ano e meio a dois anos, a partir de quando receberia sua unidade habitacional. Recebida a casa, com imissão provisória na posse, as parcelas de pagamento eram majoradas. Nos termos do contrato que examinamos, datado de 1967 , o comprador deveria pagar mensalmente $1 \%$ do preço total, por um prazo de tempo não-determinado, todavia, até a imissão provisória na posse de sua residência. Imitido na posse, passaria a pagar mensalmente $1,5 \%$ do valor do contrato.

Os valores não eram fixos. As parcelas mensais de pagamento variavam de acordo com o salário mínimo, enquanto o valor remanescente do contrato era reajustado monetariamente pela variação dos preços da construção civil. Desta forma, mesmo aqueles que conseguissem pagar suas prestações em dia, nunca chegariam a quitar o valor total do contrato, cujo saldo remanescente era reajustado por outro critério que, historicamente, varia acima do salário mínimo.

Apesar de não fixar a data de recebimento da residência, o contrato examinado estabelecia que da data de sua assinatura o promitente comprador estava obrigado no pagamento dos impostos e taxas que incidissem sobre o imóvel. O contrato, também, estabelecia que, até a quitação total do preço, o promitente comprador ficaria provisoriamente na posse do imóvel. Desta forma, a empresa loteadora não tinha dificuldades em reaver e revender as residências daqueles que atrasavam os pagamentos, mesmo sendo o parcelamento clandestino.

De qualquer forma, completados os períodos de carência dos primeiros compradores, nenhuma das 516 casas estava acabada, tampouco haviam sido feitas ligações de luz, de esgotamento sanitário e águas pluviais, ou calçamentos. É claro que as prometidas linhas de crédito jamais foram obtidas, face à clandestinidade da ocupação. Mesmo assim, e ainda considerando a majoração das prestações mensais, os compradores preferiram tomar posse de suas residências.

Neste ínterim, enquanto o "bairro" ia precariamente se formando e novas vendas iam sendo feitas, o Sr. Humberto Reis Costa aproximava as cercas de sua 
propriedade (Planta 6) ${ }^{11}$ em direção ao Novo Lar. Costa era de fato proprietário de uma área de terras a alguns quilômetros do bairro.

Aparentemente, o sucesso daquele empreendimento imobiliário fez com que, de forma pouco ortodoxa, resolvesse dividir os lucros obtidos pela loteadora clandestina, obrigando que os promitentes compradores passassem a pagá-lo. De fato, quando suas cercas chegaram à vizinhança do "Novo Lar", no início dos anos 70, o Sr. Costa começou a dizer no "bairro" que era o verdadeiro proprietário daquelas terras e procurava ganhar confiança dos adultos, tratando bem seus filhos, dando-lhes bolas e camisetas de futebol.

Naquela época, os moradores já tinham bons motivos para duvidar da honestidade e boas intenções da loteadora. Assim, não queriam mais fazer acordos e celebrar contratos com quem não apresentasse a documentação necessária para a final transferência da titularidade. Então, os moradores haviam aprendido que, além do título de propriedade, o pretenso proprietário deveria apresentar o projeto de parcelamento aprovado.

Considerando que Costa não apresentava tal documentação e que se não pagassem a Lar Nacional acabariam por encarar uma reintegração de posse, continuavam os pagamentos para a loteadora, até a data em que esta fechou seus escritórios e seus sócios sumiram no tempo e no espaço pouco tempo depois.

Desaparecidos os sócios da Lar Nacional, Costa aumentou sua pressão sobre os moradores, jogando lixo para poluir o lago onde era captada a água para as residências e fazendo despejos forçados de algumas famílias. Assim, os pais saiam para trabalhar e quando voltavam encontravam seus móveis e filhos na rua e outra família em sua casa. A poluição da água não afetava todos os moradores, pois muitos já haviam construído poços artesianos em suas casas. No entanto, os despejos forçados assustaram a comunidade.

Desta forma, resolveram constituir uma Associação de Moradores, onde pudessem discutir e resolver os problemas comuns. Além disso, criaram uma rede de comunicação encarregando as donas de casa do "bairro" de avisarem seus maridos, quando os caminhões de Costa aparecessem no local para trazer novas famílias. Os maridos, por sua vez, haviam obtido autorizações de seus chefes para voltar para casa na hipótese de receberem telefonema. Assim, conseguiram resistir às evicções arbitrárias.

11. Esta ć a planta de localização dos dois lotcamentos como se cncontram hoje registrados $\mathrm{cm}$ CASE 3, na Prefeitura Municipal de São Paulo. 
Por outro lado, além de terem um local para se reunirem precisavam constituir formalmente a Associação, portanto precisavam de um advogado. Mesmo porque, no início dos anos 70 , muitos outros grupos de pessoas apareceram alegando ser os verdadeiros proprietários da área. Nesta época, um advogado apareceu no local, alegando querer comprar uma casa. Este advogado obteve a constituição formal da sociedade e defendeu vários moradores nas ações de reintegração de posse promovidas pela Lar Nacional.

No entanto, não os auxiliou no deslinde da questão fundiária propriamente dita. Ao longo do tempo, percebeu-se que o advogado prestava serviços para o $\mathrm{Sr}$. Costa; logo seu trabalho consistia em resguardar seus interesses e não o de promover aqueles da comunidade. Na verdade, tal deslinde era mesmo tarefa difícil.

Muitos poderiam reclamar a propriedade sobre a área, inclusive o Estado de São Paulo, tão vagas são as descrições das glebas de terras nos títulos de propriedade. Não existe qualquer registro da maioria dos marcos apontados, impossibilitando a reconstrução dos perimetros. Desta forma, sem a representação cartográfica qualquer solução seria, na melhor das hipóteses, discricionária. E, discricionárias foram as decisões tanto do Poder Judiciário, quanto da Prefeitura Municipal de São Paulo nas disputas travadas entre Costa e a empresa loteadora que examinamos adiante.

\subsection{Os Títulos de Propriedade}

Antes de examinarmos as lides propriamente ditas devemos examinar os títulos de propriedade que as respaldaram. Todos os títulos conflitantes tiveram a mesma origem, a saber: a Fazenda Oratório. Esta fazenda, provavelmente recebida em sesmaria, chegou à propriedade de João Cardoso de Siqueira e sua mulher no século XIX.

Reis Costa alegava ter adquirido suas terras de alguém que, através de longa cadeia sucessória, seria o sucessor dos direitos dominiais de João Cardoso de Siqueira. ${ }^{12}$ De qualquer forma, obteve o registro da transcrição, em 1951. A companhia Lar Nacional e sua sócia Pérola de Sá Franco, por sua vez, adquiriram suas glebas de um terceiro, João Boaventura, que alegava ser inventariante de André de Jesus. As aquisições tanto da loteadora, quanto de sua sócia ocorreram mais de uma década após

12. Atć o momento, não localizamos os autos dos inventários alcgados por Costa cm ação demarcatória promovida por supostos succssores de André de Jcsus. De qualquer forma, o TJ-SP outorgou-lhe mandado de reintcgração de possc sobre parte do antigo Sitio de André de Jesus. 
o registro da transcrição obtido por Costa, pois se deram por volta de 1967. Todavia, também foram transcritas na forma da Lei então vigente.

André de Jesus comprou uma "sorte de terras" de João Cardoso de Siqueira e de sua esposa, em 1844, conforme declarou perante o Registro Paroquial em 1854. Ocorre que, segundo consta, enquanto a morte dos Siqueira teria originado inventários, tendo o último, devido pelo falecimento da esposa, encerrado em 1860, a sucessão de André de Jesus é nebulosa. A data do falecimento de André de Jesus teria ocorrido por volta de 1868, sendo certo que seu primeiro inventário só foi aberto em 1928.

$\mathrm{Se}$, de fato, no que tange à filiação, aparentemente o título de Costa estava melhor respaldado que os títulos da loteadora, por outro lado estando todos registrados, nos termos do art. 530, inciso I, do Código Civil, não haveria que ser falado dogmaticamente que um título era melhor ou pior que os outros. Os títulos que respaldavam os direitos da loteadora são melhor descritos, já que fornecem ao menos as medidas lineares de suas confrontações. Mesmo sendo estas descrições desvinculadas da realidade cartográfica, dificultando a visualização e localização das terras que descreviam, ao menos trazem as medidas lineares. O mesmo não ocorre com a descrição das glebas transcritas por Costa, que segundo o registro perfazia um total de cerca de 150 acres de terra, nem com a descrição das terras deixadas por André de Jesus, que segundo seu segundo inventário, aberto em 1969, perfazia um total de cerca de $1.867 \mathrm{mil} \mathrm{m}^{13}$

Apesar das descrições nebulosas as terras adquiridas por Costa e a descrição feita, em 1969, das terras deixadas por André de Jesus é fácil verificar que se confrontam. Ambas mencionam a confrontação com o Córrego Anhumas e, mais relevante, um dos confrontantes mencionados no título de Costa aparece como herdeiro de André de Jesus no inventário aberto em 1969. Porém, das descrições havidas nos vários títulos não se pode afirmar que as terras da loteadora e as terras de Costa sequer se confrontassem. No entanto, as decisões administrativa e judicial perceberam não-só uma confrontação, mas até uma superposição de títulos.

\subsection{As lides judiciais}

Os moradores, como expusemos acima, estavam muito confusos e acabaram por se organizarem para poderem enfrentar seus problemas. Tinham toda a razão. Os conflitos se travaram, sem que tivessem sido informados oficial ou oficiosamente. Segundo relataram, souberam que para sua solução havia necessidade

13. Das petiçõcs constantes nos documentos cxaminados, não constam o númcro dessc processo, ncm a data da distribuição da petição inicial. 
de ser decidido um processo que estava em Brasília. A Lar Nacional os havia informado, através de seus sócios, que instaurara o processo para a regularização do parcelamento. Os moradores nada sabiam dos conflitos entre a loteadora e Costa e só foram saber que havia um misterioso processo em Brasília após o sumiço dos sócios da Lar Nacional.

Não sabiam que os conflitos foram deflagrados tão-logo Costa chegou com suas cercas nas divisas do loteamento e muito menos que estes se operavam tanto no nível administrativo, quanto no nível Judiciário.

De fato, havia a ação de reintegração de posse distribuída à 6" Vara Cível da Comarca da Capital ${ }^{14}$. que aguarda, para sua cabal execução, decisão de outra ação enviada ao Supremo Tribunal Federal, em 12 de março de 1973, até hoje nãosolucionada. A ação que correu perante a $6^{a}$ Vara Cível foi uma reintegratória que João Boaventura (inventariante de André de Jesus nos títulos da Lar Nacional) moveu contra Costa e sua esposa. A sentença de Primeira Instância reconheceu a procedência da ação. Costa apelou e o Tribunal de Justiça modificou aquela decisão, reconhecendo os direitos de Costa, que fez executar o acórdão em 1972.

A execução da sentença foi contestada por embargos de terceiros da loteadora, em 18 de outubro de 1972, e de Pérola de Sá Franco, em 20 de outubro daquele ano. O mandado manda reintegrá-lo na posse de uma área de $1.422 .094 \mathrm{~m}$ de área maior do "Sítio André de Jesus" O mandado de reintegração expedido, em 29 de agosto, não faz qualquer referência à Fazenda Oratório ou às terras deixadas por João Cardoso de Siqueira e sua esposa, de cujo sucessor Costa alega ter comprado em sua contestação, nos autos do processo n. 3.382/79, da ação ordinária de demarcação e divisão que correu perante a $16^{\mathrm{a}}$ Vara Cível

Os embargos de terceiro distribuídos suspenderam o feito. Todavia, os embargos de terceiro promovidos pela Procuradoria do Patrimônio do Estado de São Paulo, em 14 de novembro de 1972, transferiram a competência do feito para a $3^{\text {a }}$ Vara da Fazenda Estadual, em 9 de março de 1973. ${ }^{15}$ A Procuradoria do Estado alegava, em síntese, que o título de João Boaventura era espúrio, porque suas terras localizavam-se dentro de área maior, na margem esquerda do Rio Tietê que, nos termos da decisão do Supremo Tribunal Federal, cabiam em condomínio ao Banco Evolucionista e ao Estado

14. Tambćm, para cstc processo, nào foi possivel localizar o númcro.

15. Estc processo englobava uma parte da árca comercializada, c não o total de 10 mil residências que cstavam sendo compromissadas à venda. 
de São Paulo. Ainda, alegou que do total de 25 mil hectares, os 12,5 mil hectares que couberam ao Banco já haviam se esgotado com a alienação de área superior a 15,353 mil hectares de terras.

Paralelamente, corria outra ação de reintegração de posse. A ação que a Companhia Melhoramentos e Urbanização Kiaja, na qualidade de sucessora do Banco Evolucionista, e um certo coronel José Paulini promoviam contra a empresa perante a $8^{\mathrm{a}}$ Vara da Justiça Federal, em São Paulo. Naquela ação as Fazendas do Estado e da União apresentaram oposição.

A Fazenda do Estado, que havia sido chamada para integrar a lide como litisconsorte ativa e comunheira, havia ingressado com oposição, alegando o mesmo que na outra reintegratória. A oposição promovida pela União Federal, em 1972, requereu a exclusão do feito da autora, da ré e da oponente, tendo em vista a alínea $h$ ), artigo $1^{\circ}$, do Decreto-lei n. 9.760/46 que dava à União Federal o domínio sobre os extintos aldeamentos indígenas. De fato, a área em discussão encontra-se, de fato, dentro do perímetro do extinto aldeamento de São Miguel-Guarulhos e do perímetro de terras concedidas ao engenheiro Medina.

Em suas alegações a União desconheceu o acórdão, de 1928, do Supremo. Ainda, afirmava que não-reconhecia a legalidade da concessão feita pelo Estado de São Paulo ao Banco Evolucionista, em 1892, pois o título infringira o art. 11, da Lei n. 840 , de 15 de setembro de 1855 , que determinava a necessidade de escritura pública.

Nem vamos aqui considerar as outras questões de alta indagação jurídica levantadas pela União como, por exemplo, o fato de a área do extinto aldeamento indígena não ser terra devoluta. Desta forma, o Estado de São Paulo não teria qualquer direito sobre elas nos termos do art. 64, da Constituição Federal, de 1891. Percebemos, em uma primeira análise, que todas as questões jurídicas suscitadas tinham caráter formal, desconheciam o fato que as pessoas físicas e jurídicas de Direito Privado tinham título de domínio registrado e absolutamente desconsideravam os reflexos das discussões que travavam na população diretamente envolvida.

$\mathrm{O}$ fato é que todos aqueles títulos de origem duvidosa e de descrição nebulosa, diante da ausência de representação cartográfica, foram registrados, o que os tornava válidos e oponivel a terceiros, nos termos da legislação-pátria. Tanto assim é, que a ação originária n. 210-9 ainda se encontra no Supremo, transferida à relatoria do ministro Maurício Corrêa, em 1995.

A complexidade da lide perturbou, naquele momento, a Procuradoria do Estado. Esta, em 9 de abril de 1973, peticionou ao Juizo da $3^{\text {a }}$ Vara da Fazenda Estadual, 
informando a existência do feito, discutindo sobre área maior que, diante do interesse da União e do Estado, fora remetido da $8^{\mathrm{a}}$ Vara da Fazenda Federal ao Supremo Tribunal Federal. Outrossim, informou àquele Juízo que além da oposição naquele feito requerera medida acautelatória de seqüestro "face ao problema social criado" Mesmo assim, diante do interesse manifestado pela União no outro feito, requereu a remessa dos autos à Justiça Federal e o sobrestamento daquele processo até o final julgamento do outro feito pelo Supremo.

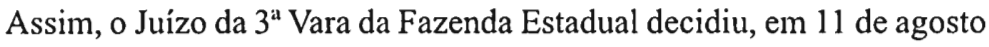
de 1973, pela suspensão do feito e dos seus respectivos embargos de terceiros até a data em o outro processo fosse julgado pelo Supremo Tribunal Federal. Dos documentos examinados consta a inicial da oposição, distribuída em 28 de maio de 1982, promovida perante a $3^{\text {a }}$ Vara da Fazenda Estadual pelos moradores do loteamento "Novo Lar" na qualidade de compromissários compradores da Lar Nacional contra João Boaventura e Humberto Reis Costa e respectivas esposas, face à execução da sentença havida pela decisão da reintegração de posse.

Aquela oposição trouxe finalmente, após uma década, perante o Poder Judiciário a discussão sobre os direitos dos adquirentes de boa-fé e moradores do "bairro" A oposição fez-se necessária, pois Costa queria fazer cumprir o mandato de reintegração que obtivera contra a loteadora que estava, como expusemos acima, suspenso.

A sentença que decidiu esta oposição nada mencionou sobre os direitos dos moradores. Aquele Juízo entendeu, em 30 de junho de 1982, pelo indeferimento da oposição pois a execução da sentença reintegratória já havia transitado em julgado e que a Lar Nacional obtivera liminar de manutenção de posse sobre parte da área. Todavia, ambos os feitos estavam suspensos, logo a oposição era incabível. Mesmo tendo indeferido aquela ação e mesmo relevando os interesses dos moradores, a decisão foi para eles importante, porque impediu Costa de continuar com os despejos arbitrários que promovia.

Por outro lado, nos termos da certidão objeto e pé expedida pelo Supremo Tribunal Federal, em 06 de outubro de 1982, os autos da lide entre a União, o Estado de São Paulo, as empresas Kiaja e Lar Nacional, encontravam-se com o ministro relator. Até o momento, a única mudança processual foi a alteração do ministro relator.

\subsection{A Disputa Administrativa}

Enquanto as lides acima relatadas se travavam no Poder Judiciário, outro conflito, entre Humberto Reis Costa e a Lar Nacional, se desenrolou em procedimento 
administrativo perante a Prefeitura Municipal de São Paulo. Esta disputa, iniciada em 1970, foi deflagrada pela apresentação nos autos do processo administrativo n. 104.190/ 69 do acórdão, autorizando a reintegração de posse de Humberto Reis Costa.

Através daquele processo administrativo a Lar Nacional Construtora e Administradora Ltda. pleiteava a aprovação do parcelamento, que de fato já fizera e comercializava. ${ }^{16}$ Costa informou sobre a existência do litígio esclarecendo que a lide versava sobre apenas cerca $69 \mathrm{mil} \mathrm{m}^{2}$ do total de $278.449,00 \mathrm{~m}^{2}$ que a Lar Nacional pretendia arruar.

Apesar de Costa reconhecer, naquele procedimento administrativo, a propriedade da Lar Nacional sobre a área de cerca de $221 \mathrm{mil} \mathrm{m}^{2}$ aquele processo durou mais de dez anos. Foi resolvido independentemente da resolução judicial das

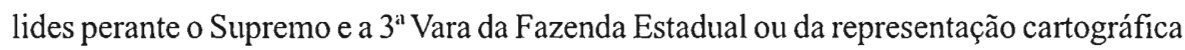
das áreas.

Parecer, datado de 14 de julho de 1970, informava que o Código de Obras em vigor determinava que o arruador deveria apresentar os títulos de propriedade da área que parcelava provando o domínio e que provasse a ausência de litígio sobre a gleba. O parecer sugeria que a Lar Nacional apresentasse novo pedido de aprovação de arruamento sobre a área de $221 \mathrm{mil} \mathrm{m}^{2}$ sobre a qual não havia litígio.

A Lar Naciona" seguiu o parecer. Todavia, as certidões negativas dos distribuidores deveriam ser apresentadas também em relação aos antecessores da arruadora. Ocorre que havia uma ação demarcatória e divisória, perante a 20" Vara Cível da Comarca da Capital contra um dos antecessores da loteadora. E, quando, em 1972, a Cia. de Melhoramentos e Urbanização Kiaja distribuiu a ação de reintegração de posse perante à Justiça Federal, a apresentação de Certidão Negativa dos Distribuidores Federais restou irremediavelmente impossível.

De qualquer forma, em 1971, a loteadora havia recebido parecer favorável para a obtenção do Alvará, pois apresentara toda a documentação necessária. O Alvará "Termo de Compromisso e Autorização" - foi expedido em 10 de janeiro de 1972. Porém, entre março e abril daquele, ano o setor de engenharia descobriu, através de estudo de campo, sem aparelhos, com base em planta da Light, que o Alvará concedido não correspondia a gleba inscrita nos 221 mil m_de propriedade da loteadora. Mesmo assim, foi autorizada; pelo engenheiro chefe da divisão, a lavratura de Alvará de

16. A propricdade imóvel reconhecida como Dircito Humano, $\mathrm{cm} 1789$, trouxc outros problcmas, que comcçam a scr atacados atravćs da função social da propricdade. 
"regularização de arruamento e loteamento".

O processo seguiu para o Departamento de Patrimônio para a doação das ruas à Municipalidade. Em 09 de novembro de 1972, foi enviada equipe técnica ao local que constatou que "o loteamento em questão encontrava-se em fase adiantada de execução", prédios com alvará de construção e "habite-se" outros clandestinos com autos de infração, multas e embargos. Constatou, ainda, que a Prefeitura Municipal de São Paulo intimara a Lar Nacional, em 16 de março de 1970, para regularizar o loteamento no prazo de 45 dias. Deste episódio, relatado nos autos de regularização na Empresa Municipal de Urbanização - Emurb, em 12 de março de 1981, fica clara a total falta de integração entre os diferentes órgãos da Prefeitura Municipal de São Paulo.

Ainda, em 1980, a Prefeitura Municipal constatou que a empresa Lar Nacional não mais existia e que seu procurador residia em local incerto e desconhecido. Em novembro daquele ano, fora realizada nova vistoria no local e a regularização fora novamente autorizada. Segundo os moradores, de fato, várias equipes da Municipalidade estiveram no local. Todavia, ninguém se lembra de ter visto equipes com aparelhos topográficos.

Desta forma, o processo administrativo foi resolvido, em 1984, sem qualquer respaldo técnico. A Prefeitura Municipal decidiu que os títulos de propriedade se sobrepunham em parte. Deliberou que cerca de um terço da área seria integrada ao loteamento Sapopemba de Reis Costa e reconheceu que cerca de dois terços era de fato da Lar Nacional (Planta 6). Finalmente, autorizou a regularização pela Prefeitura, nos termos da Lei n. 6.766/79, da parte que reconheceu como sendo de propriedade da loteadora.

A parte que passou a integrar o "Jardim Sapopemba" obteve regularização fiscal. Os impostos são, até hoje, lançados em nome de Costa e seus filhos. Os calçamentos, a ligação, a canalização das águas e o esgotamento sanitário à rede pública, foram integralmente custeados pelos moradores. As ligações à rede pública de luz e força fora obtida anteriormente.

Na verdade, a decisão administrativa respaldou-se em um acordo fora dos autos do processo, e que não o integrou. Por este acordo, fomentado pelo então presidente da Emurb, os sócios da loteadora e Reis Costa acordaram naquela divisão da área.

Os moradores não foram consultados para opinar sobre o acordo oficioso. Assim, os moradores que compraram seus lotes e casas da Lar Nacional, há trinta anos, promovem ações de usucapião urbano para terem reconhecido o domínio sobre 
seus imóveis. Nestas ações, sofriam a oposição da União e a contestação dos sucessores de Reis Costa.

Aquelas ações seguem sendo contestadas por Reis Costa. Há cerca de um mês foi julgada uma de suas apelações, para indeferi-la. Os autos ainda não retornaram ao Cartório. Quando retornarem, será a primeira confirmação do domínio no "bairro" para cerca de cem desses ações propostas a partir de 1992.

\section{Conclusão}

A ocupação ilegal do solo urbano paulistano volta ao debate. Segundo as entrevistas e reportagens que vêm sendo publicadas pela mídia, o governo democrático, que será instalado em janeiro de 2001, promoverá a regularização fundiária da Cidade. Já não era sem tempo que houvesse uma gestão municipal que priorizasse a inclusão social e espacial dos moradores desta Cidade.

Hernando De Sotto apontou a importância que o reconhecimento do direito de propriedade privada teve para o desenvolvimento da economia européia no século XVIII. Então, foram quebradas as relações existentes desde a Idade Média sobre a terra e admitida a existência da propriedade privada como um direito do cidadão. ${ }^{16}$ No entanto, a maioria dos estudos internacionais mostra que antes que o domínio pleno é muito importante obter a segurança na posse como instrumento de combate à pobreza urbana nos países em desenvolvimento.

No Brasil, devido nossa legislação sobre propriedade, é difícil pensarmos em segurança na posse sem o registro do título. Assim, seja a ocupação do solo assentada em área de propriedade pública ou privada a segurança só será obtida, através da aquisição do domínio útil ou pleno. Este reconhecimento pressupõe o registro dos instrumentos de aquisição da propriedade, plena ou-não.

A insegurança na posse afeta a vida de milhões de brasileiros. Uma pesquisa bastante conservadora ${ }^{17}$ estima que metade da população da Cidade de São Paulo viva em assentamentos informais. Isto significa que, só nesta Cidade, pelo menos 5 milhões de pessoas vivas precariamente, sem segurança sobre a posse de suas moradias.

Estes dados já são sérios por si-só. Mais sérios ficam quando percebemos que tampouco o registro do título trará a almejada segurança. Esta foi precisamente a situação enfrentada pelos adquirentes dos lotes e casas oferecidos ao mercado pela Lar

17. Pesquisa feita pela Fundação Instituto de Pesquisas Econômicas (Fipc) $\mathrm{cm}$ 1994, publicada pelo jornal Folha de S.Paulo, domingo, 4 de junho, 2000, p. Cl. 
Nacional Construtora e Administradora Ltda., em São Mateus. Ora, apesar de não ter aprovado e registrado o loteamento anteriormente ao oferecimento dos lotes e casas, em cumprimento à determinação legal, aquela empresa tinha um título registrado.

Tendo um título registrado na região, com área suficiente para abrigar os cerca de 500 lotes que primeiramente implantava e vendia, mesmo que um pretenso adquirente contratasse um advogado para examinar a documentação disponivel, o máximo que o experto poderia dizer é que se tratava de um parcelamento clandestino. Ninguém poderia afirmar, a partir do exame da certidão de propriedade, que a área registrada não abrangesse a área loteada. Da mesma forma, as glebas registradas em nome de Pérola de Sá Franco, para onde estavam planejadas a implantação das demais 9,5 mil residências

Não poderia e não-pode. É impossível fazer o levantamento mapográfico, a partir dos marcos dados na descrição daquela certidão de propriedade para saber se a área abrangia todo o loteamento (Plantas 4 e 5). Como não se obtém qualquer resultado, tentando-se lançar os marcos dados da área registra de Humberto Reis Costa demonstra. Desta forma, a decisão da Prefeitura Municipal de São Paulo ao dividir a área (Planta 6) foi totalmente arbitrária.

No último mês de maio, o Partido dos Trabalhadores (PT) publicou e divulgou seu programa nacional de moradia. Lá, quando abordada a questão da discriminação das áreas públicas é dito que: "os exemplos que mostram ambas confusões, entre proprietários e os limites de suas propriedades, são infinitos (...) causados principalmente pela ausência de cadastro confiáveis e bem organizados em nossos Cartórios de Registro de Imóveis." ${ }^{18} \mathrm{Na}$ verdade, nossos estudos demonstram que a pouca confiabilidade dos títulos registrados, no que tange os limites da propriedade originando infinitos confrontos entre proprietários, é sim um problema de estrutura organizacional, todavia de outra ordem.

A questão diz respeito à legislação federal que normatiza a organização funcional dos Serviços Imobiliários. Desta forma, ao vincular tais serviços ao Poder Judiciário e não ao Município e ao desobrigar a necessária correspondência entre o mapa da Cidade e o título registrado, não existe maneira possível de dar total segurança aos títulos registrados e, conseqüientemente, evitar os constantes litígios.

Por outro lado, a estrita ligação entre os mapas cadastrais e o título registrado pode não ser suficiente para resolver o caos registrário hoje existente. Para 
tanto, há necessidade premente de haver uma unificação entre os vários cadastros imobiliários. Percebemos que é impossivel, ou pelo menos muito dificil, promover uma ampla reforma urbana, através da regularização fundiária sem unificá-los.

Como pode o Governo municipal cumprir suas obrigações constitucionais se desconhece os proprietários do solo que deve administrar, nos termos do art. 182? A União mantém seu próprio cadastro dos imóveis urbanos, que integram seu patrimônio, nos Serviços do Patrimônio da União. Cada Estado-membro, através de seus respectivos Poderes Judiciais é responsável pela gerência de todos os serviços registrários dentro de seu território. ${ }^{19}$

Finalmente, cada um dos quase 6 milhões de Municípios brasileiros mantém o seu cadastro imobiliário. $\mathrm{O}$ problema não é só o número de diferentes cadastros existentes, o que representa pouca economicidade e dificuldade de controle de quem quer que seja. A questão é que não existe qualquer conexão entre estes cadastros.

O programa nacional para moradia, acima mencionado, afirma que não é por falta de normas jurídicas que a ocupação do solo urbano brasileiro é caótica. ${ }^{20} \mathrm{De}$ fato, não faltam normas jurídicas. O problema, portanto, não é a quantidade e, sim, da qualidade das normas jurídicas. O conjunto legal regulamentador do espaço urbano não é eficaz à produção de uma Cidade que cumpra sua função social.

A legislação urbanística, aliada à prática da política clientelista, propiciou a visível exclusão espacial das cidades brasileiras. Todavia, não se trata somente da legislação urbanística. Esta encontra respaldo no ordenamento jurídico nacional, especialmente na concepção da propriedade como reserva de valor e no cadastramento que é feito desta propriedade.

Cirne Lima disse que as descrições imprecisas dadas às sesmarias eram propositais. Desta forma, a Coroa portuguesa manteve os sesmeiros brigando entre si para definir os limites de suas terras e não com a metrópole. A afirmação é bastante razoável. De fato, se tinham os portugueses os instrumentos de navegação necessários para cruzar oceanos, certamente dominavam a tecnologia para mapear precisamente as terras que concediam. O que não é razoável é a manutenção, mutatis mutandi, do mesmo princípio colonialista quinhentos anos após sua implementação.

O País independizou-se há quase duzentos anos. Há mais de cem anos é um Estado laico independente da Igreja Católica. No entanto, a imprecisão dos títulos

19. Somente para a Comarca c Município de São Paulo cxistem 18 Cartórios de Registro de Imóvcis. 20. Ib., p.34 
de propriedade é uma constante. Do aval da Coroa à concessão das sesmarias, dos Registro Paroquiais aos nossos atuais Serviços de Registro de Imóveis pouco mudou. Certamente, não houve qualquer modificação ao longo destes cinco séculos no que tange a vinculação entre a representação gráfica do imóvel, o título de propriedade e sua real inserção no mapa cadastral da Cidade. ${ }^{21}$

Publicada a Constituição Federal, de 1988, a grande maioria da doutrina pátria reconhece as profundas modificações trazidas ao conceito de propriedade. Hoje, não mais podemos dizer a propriedade seja um instituto do Direito Privado. A função social da propriedade urbana, não só limita seu exercício, através de normas urbanísticas, mas integra o próprio Direito.

A extensão da função social altera o conceito de propriedade imóvel, oriunda do Código de Napoleão, de 1804, favorecendo o exercício da moradia e a real ocupação do imóvel. Protege os ocupantes até contra o proprietário que não cumpra sua função social. Ao ponto de Fábio Konder Comparato, por exemplo, afirmar que nenhum direito à propriedade resta àquele que não a faz cumprir sua função social.

Esta percepção é correta. Todavia, seu reconhecimento é difícil na prática, quando verificamos a grande maioria das decisões judiciais. O Poder Judiciário brasileiro tende ao positivismo. Desta forma, enquanto não houver a positivação do novo conceito de propriedade a jurisprudência majoritária continuará impondo o velho conceito.

De qualquer forma, a questão não é o Poder Judiciário, nem sequer modificações legislativas para a mudança de conceitos. A questão é mais profunda. Trata-se da necessidade de uma mudança na própria estrutura em que se respalda o direito de propriedade, ou seja, na forma como se dá seu registro.

Somente um registro de propriedade unificado, que vincule o título à sua representação gráfica na malha urbana (ou rural) tornará, além da segurança ao registro, possível obrigar o cumprimento da função social da propriedade. A desconexão hoje existente, no mínimo, dificulta a missão constitucional dada ao Poder Municipal de implantação de uma Cidade que cumpra sua função social.

A apontada desvinculação perpetua a necessidade de regularização fundiária. Assim, conforme o discutido durante a $7^{\text {a }}$ Conferência do IRGLUS, em julho deste ano, no Cairo, a necessidade da regularização fundiária é um tema permanente. Será, de fato, perene, enquanto não enfrentarmos as modificações estruturais que se fazem necessárias. 
Para o País, no que tange ao direito de propriedade imobiliária, entendemos que a primeiríssima modificação a ser feita é na forma pela qual se dá seu registro. Sem esta alteração, dificilmente a propriedade atingirá sua função social e jamais deixaremos de necessitar a periódica regularização fundiária.

São Paulo, dezembro de 2000. 
Bibliografia

AMARAL Júnior, Alberto do: Proteção do Consumidor no Contrato de Compra e Venda, São Paulo, Editora Revista dos Tribunais, 1995.

AZUELA, Antonio: La Ciudad, la Propiedad Privada y el Derecho, Cidade do México, México, El Colegio de Mexico, 1999.

BARRUFINI, José Tosetti: Usucapião Constitucional Urbano e Rural, São Paulo, Editora Atlas, 1997.

CASTELLS, Manuel: Cidade, Democracia e Socialismo. São Paulo, Editora Paz e Terra, 1989.

CENEVIVA, Laura Lúcia e SILVA, Helena Barreto, in La Regularisation des Etablissements Irreguliers dans le Villes des Pays en Developpements, coordenação de Alain Durand-Lasserve, apoio do Banco Mundial, seminário no México, 1993.

CENEVIVA, Walter: Lei dos Registros Públicos Comentada, São Paulo, Editora Saraiva, 1988.

CIRNE LIMA, Ruy: Pequena História Territorial do Brasil, Brasília, DF, Escola de Administração Fazendária (ESAF), 1988.

COMPARATO, Fábio Konder: Direitos e Deveres Fundamentais em Matéria de Propriedade in O Cinqüentenário da Declaração Universal dos Direitos do Homem, organizado por Alberto do Amaral Júnior e Cláudia Perrone-Moisés, São Paulo, Edusp - Editora da Universidade de São Paulo, 1999

DEÁK, Csaba: O Processo de Urbanização no Brasil: Falas e Façanhas in $O$ Processo de Urbanização no Brasil, organizado por Csaba Deák e Sueli e Sueli Ramos Schiffer, São Paulo, Edusp - Editora da Universidade de São Paulo, 1999.

FARIA, José Eduardo: Direito e Economia na Democratização Brasileira, São Paulo, Malheiros Editores, 1993.

FARIA, José Eduardo: O Brasil Pós-Constituinte, Rio de Janeiro, Edições Graal Ltda., 1989.

FARIA, José Eduardo: Sociologia Jurídica - Crise do Direito e Práxis Política, Rio de Janeiro, Companhia Editora Forense, 1984.

FERNANDES, Edésio: Direito e Urbanização no Brasil, in Direito Urbanístico, Belo Horizonte, Livraria Del Rey Editora, 1998.

FERNANDES, Edésio: A Regularização de Favelas no Brasil: O Caso de Belo Horizonte, in Direito Urbanistico, Belo Horizonte, Livraria Del Rey Editora, 1998.

FERNANDES, Edésio e ROLNIK, Raquel: Law and Urban Change in Brazil 
in Illegal Cities - Law and Urban Change in Developing Countries, editado por Edésio Fernandes e Ann Varley, Londres, Inglaterra, Zed Books Ltd., 1998.

FERRAZ Júnior, Tércio Sampaio: Introdução ao Estudo do Direito, São Paulo, Editora Atlas SA, 1987.

FURTADO, Celso: Formação Econômica do Brasil, São Paulo, Editora Nacional, 1975.

GOMES, Orlando: A Crise do Direito, São Paulo, Max Limonad, Editor de Livros de Direito, 1955.

GOMES, Orlando: Direitos Reais, Rio de Janeiro, Editora Forense, 1980.

IMPARATO, Ellade: O Usucapião Constitucional Urbano, in Direito à Cidade, São Paulo, Editora Max Limonad, 1999.

LACERDA, M. Linhares de: Tratado das Terras do Brasil, Rio de Janeiro, Editora Alba Ltda., 1960.

KELSEN, Hans: Teoria Pura do Direito, Buenos Aires, Argentina, Editorial Universitaria de Buenos Aires, 1979.

MALUF, Carlos Alberto Dabus: Limitações ao Direito de Propriedade, São Paulo, Editora Saraiva, 1997.

MARGARIDO, Antônio Benedito: Sobre a Aplicabilidade da Função Social da Propriedade, São Paulo, Faculdade de Direito da Universidade de São Paulo, tese de doutorado, 1991.

MEIRELLES, Hely Lopes: Direito Municipal Brasileiro, São Paulo, Editora Revista dos Tribunais, 1981.

PINHO, Evangelina Bastos: Regularização Fundiária em Favelas, in Direito Urbanístico - coordenação de Edésio Fernandes, Belo Horizonte, Editora Del Rey, 1998 REALE, Miguel: Liberdade e Democracia, São Paulo, Editora Saraiva, 1987. RENNER, Karl: Gli Istituti de Diritto Privato e la loro Funzione Sociale, Bolonha, Itália, Società Editrice il Mulino, 1981.

RODOTÀ, Stefano: El Terrible Derecho Estudios sobre la Propriedad Privada, Madri, Editorial Civitas S.A., 1986.

RODRIGUES, Sílvio: Direito Civil, Direito das Coisas - Volume V, São Paulo, Saraiva S. A. - Livreiros Editores, $10^{a}$ Edição, 1980.

ROLNIK, Raquel: A Cidade e a Lei, São Paulo, Studio Nobel e Fapesp, 1997. ROLNIK, Raquel: Para Além da Lei: Legislação Urbanística e Cidadania (São Paulo 1886-1936), in Direito Urbanistico - coordenação de Edésio Fernandes, Belo Horizonte, Editora del Rey, 1998. 

Nos Registros Imobiliários Brasileiros

SAULE JÚNIOR, Nelson: Novas Perspectivas do Direito Urbanistico Brasileiro. Ordenamento Constitucional da Política Urbana. Aplicação e Eficácia do Plano Diretor, Porto Alegre, Sérgio Antônio Fabris Editor, 1997.

SILVA, José Afonso da: Curso de Direito Constitucional Positivo, São Paulo, Malheiros Editores, 1995.

SILVA, José Afonso da: Direito Urbanístico Brasileiro, São Paulo, Malheiros Editores, 1995.

SOTO, Hernando de: The Other Path The Invisible Revolution in the Third World, com colaboração do Instituto Libertad y Democracia, Nova York, EUA, Haper \& Row Publishers, 1989.

TASCHENER, Suzana Pasternak: Compreendendo a Cidade Informal, in Desafios da Cidade Informal, Nairobi, Kenya, United Center for Human Settlements, 1996.

WARAT, Luís Alberto: Mitos e Teorias na Interpretação da Lei, Porto Alegre, Editora Síntese Ltda., 1979.

\section{Artigos:}

FARIA, José Eduardo: O Judiciário e seus Dilemas in Revista do Advogado n." 56, São Paulo, Associação dos Advogados de São Paulo, setembro, 1999.

HOLSTON, James: Legalizando o Ilegal, São Paulo, Revista Brasileira de Ciências Sociais, n. 8, 1993.

VIANA, Rui Geraldo Camargo: Usucapião Popular Urbano, São Paulo, Revista de Jurisprudência do Tribunal de Justiça do Estado de São Paulo (RJTJESP) n. 101, Editora Lex, 1986.

WERNA, Edmundo: Urban Management and Intra-Urban Differentials in São Paulo, Londres, Inglaterra, Elsevier Science Ltda., habitat Int., v. 19, n. 1, 1995.

Publicações:

Projeto Moradia, coordenado por Ermínia Maricato, Lúcio Kowarick \& outros, São Paulo, Instituto Cidadania, 2000, n. 4.5.1.d

The Istambul Declaration and The Habitat Agenda, Nairobi, Kenya, UNCHS (Habitat), 1997

Report of the Recife Internacional Meeting on Urban Poverty, Nairobi, Kenya, UNCHS (Habitat), 1996

Jornal:

Folha de S. Paulo de 06.04.2000 